\title{
ROLE OF VOLUNTARY TEAMS OF PROFESSIONAL ENGINEERS IN DISSATER MANAGEMENT - EXPERIENCES FROM GUJARAT EARTHQUAKE
}

\author{
Sreenivas Sarma Paraitham ${ }^{1}$, Narayan Rao Devarashetty ${ }^{2}$ \\ ${ }^{1}$ Professor and Head, Civil Engineering Department, CBIT, Hyderabad, India - 500075 \\ ${ }^{2}$ Practicing Engineer and Chartered Valuer, Kodad, Khammam district, Telangana, India
}

\begin{abstract}
Post disaster works are of great significance and need, in any part of the globe. While these works are attempted with lot of strategic planning in the developed countries, emotion, excitement coupled with lack of a professional approach to the problem, are often seen in the developing countries, resulting in furthering the ill effects of the disaster. Earthquake hit areas are known to witness this kind of situation, attracting unprecedented rush of unrelated persons, only to add to the chaos . Professional engineers have a role to play in this context and must volunteer themselves in order to contribute for the disaster management and execute appropriate post-disaster work.

This paper presents the experiences of the authors as members of a voluntary professional team that visited Gujarat after the devastating earthquake of $26^{\text {th }}$ January, 2001.The various challenges faced by the professional engineers, both technical and nontechnical, are highlighted and the efforts made to overcome them are narrated. The technical challenges include the seismic retrofitting measures to be adopted for non-engineered constructions and reversal and replacement of inadequate and inappropriate retrofitting measures by adequate and appropriate ones. The non-technical challenges include accessing the authorities, convincing them about the need for suitable retrofitting strategies and making them evolve policies for emergency reconstruction and rehabilitation. An overview of the various reasons for the very occurrence of the disaster, is also presented. In all, it is emphasized that the professional engineers have a key role to play in the disaster management and must volunteer to act to meet the need of the hour.
\end{abstract}

Keywords: Post disaster works, Earthquake hit areas, Role of professional engineers, Disaster management

\section{INTRODUCTION}

A devastating earthquake has hit Gujarat, India , at about $08.46 \mathrm{AM}$ on the $52^{\text {nd }}$ Republic day of the country ,killing at least 20,000 people, injuring about 1,67,000 and destroying about 400,000 homes. The epicenter was about $9 \mathrm{kM} \mathrm{SW}$ of the village of Chobari in Bachau taluka of Kutch district. The earthquake lasted for over two minutes, reached 7.7 M on the moment magnitude scale and had a maximum felt intensity of $\mathrm{X}$ on the Mercalli scale .

Bhuj, situated only 20 kilometres (12 mi) from the epicenter, was devastated. Considerable damage also occurred in Bachau and Anjar with hundreds of villages flattened in Taluka of Anjar, Bhuj \& Bhachau. Over a million structures were damaged or destroyed, including many historic buildings and tourist attractions. The quake destroyed around $40 \%$ of homes, eight schools, two hospitals and $4 \mathrm{~km}$ of road in Bhuj and partly destroyed the city's historic Swaminarayan Temple and historic fort as well Prag Mahal and Aina Mahal. In Ahmedabad, Gujarat's commercial capital with a population of 56 lakhs, as many as 50 multistoried buildings collapsed and several hundred people were killed. Total property damage was estimated at $\$ 5.5$ billion. In Kutch, the quake destroyed about $60 \%$ of food and water supplies and around 2,58,000 houses - 90\% of the district's housing stock. The biggest setback was the total demolition of the Bhuj Civil hospital. The Indian military provided emergency support which was later augmented by the International Federation of Red Cross and Red Crescent Society. A temporary Red Cross hospital remained in Bhuj to provide care while a replacement hospital was built.

\section{GRIHA SEVA TEAM}

An appeal was made through news papers and other sources of information dissemination, nationally and internationally , by a leading geo-technical consultant from Chennai inviting to join him for a voluntary participation in the " professional post-disaster activity ' in the areas of Bhuj and Ahmedabad. A team of Seventeen members (photo-1) was formed and named 'Griha Seva', which consisted of professionals from various disciplines including two material scientists from outside the country. The authors were the only two picked up from the then combined state of Andhra Pradesh.

It was interesting to note that a retired military major was appointed as the 'Team Manager' to activate the team members and to maintain discipline among the team 
members and in the activities of the team. A leading local architect of Ahmedabad city was picked up to help the team in accessing the authorities and the quake-hit sites. This really worked well and the architect besides taking care of these aspects, has done a commendable job in providing hospitality and accommodation .

\section{SITE VISITS AND ACTIVITY OF THE TEAM}

The team which consisted of varied professionals such as Structural engineers, Geotechnical engineers, Architects, surveyors, material scientists, Geologists, Testing experts and field assistants, was led by a geotechnical expert from Chennai and was ably supported by one local architect, in accessing the authorities and the sites . In a total of about two weeks program during the last part of February, 2001, the first few days were spent in Bhuj and then the activity was shifted to Ahmedabad.

In both the places, the activity consisted of visiting the already identified critical sites/structures, making visual inspections, gathering the details by enquiry, by measurements, by observation etc., conducting suitable insitu tests (photo-2) wherever necessary ,making a preliminary assessment of the damage to the building/ structure and suggesting emergency measures wherever needed . consolidation of the data , detailed analysis, discussion and finalization of retrofitting/ rehabilitation strategy was usually happening in the evenings, back home.

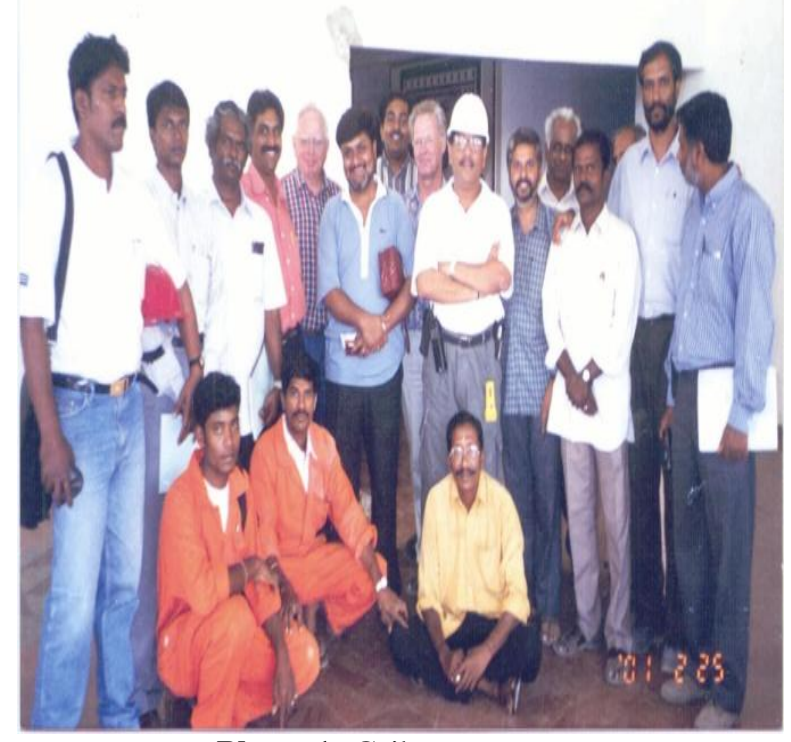

Photo-1: Griha seva team



Photo-2: In-situ tests

The proposed action plans were submitted to the team leader who in turn used to meet the authorities (mainly the Collector of the district ) with the help of the local architect , take the guidance, approval and then reaching those identified sites again in the morning next day to get the proposed rehabilitation measures executed . At least twenty sites in Bhuj and Fifty sites in Ahmedabad were visited. However, due to various reasons, it was possible to conduct a detailed inspection, make a comprehensive analysis, provide recommendations for emergency rehabilitation measures, get the approval and implement the same on the field - only for twenty buildings , in Ahmedabad city .

\section{DAMAGE PATTERNS OBSERVED}

Bhuj was more severely effected than the city of Ahmedabad . Many villages in the proximity of Bhuj such as Bachau, Anjar, Rapar were totally brought down and remained as rumbles, when the team visited. The buildings in all these villages were of mud or stone masonry. The city of Bhuj was having both - masonry structures ( mostly in the old city ) and framed RC structures ( mostly in the new city ) as well. Severe cracking was seen in almost all parts of all the buildings in Bhuj. Scenes of any building surviving the quake without cracks were very rare! The crack patterns ranged from characteristic ' $X$ ' cracking in walls (photo-3) to intensive wide spread cracking (photo-4) in the entire building structure. The damage ranged from distress in structural elements of the buildings to total collapse of the structures. Several buildings were seen sunken in to the ground ; some of them which were multi-storied were brought down by one to two stories .Buildings hitting the adjacent buildings by pounding action, crushed beam column junctions, buckled columns with crushed concrete and bent reinforcing bars (in to $2^{\text {nd }}$ and even $3^{\text {rd }}$ modes )were commonly seen. 


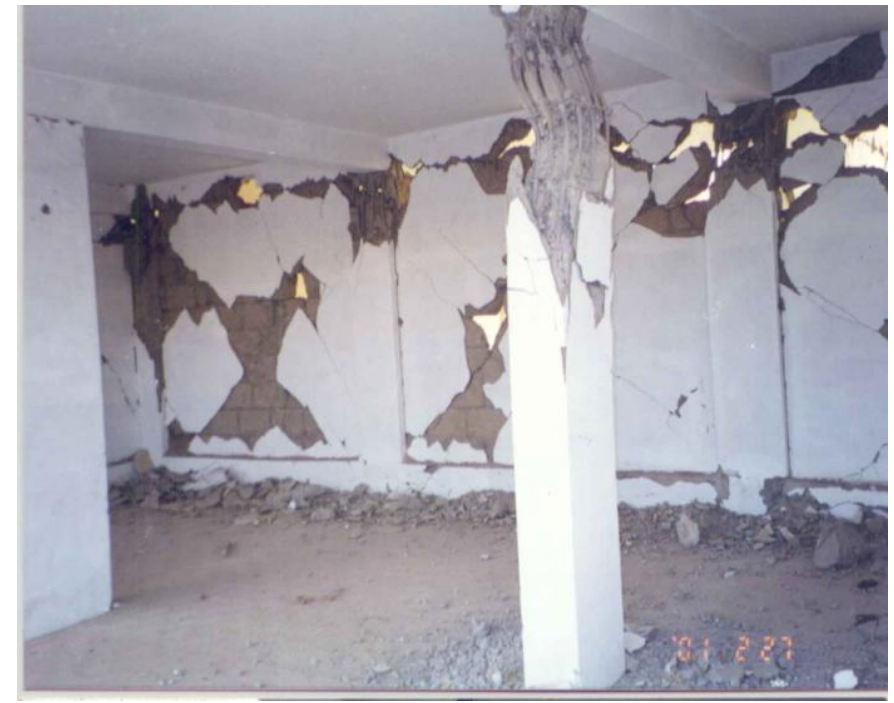

Photo-3: ' $\mathrm{X}$ ' cracking in walls

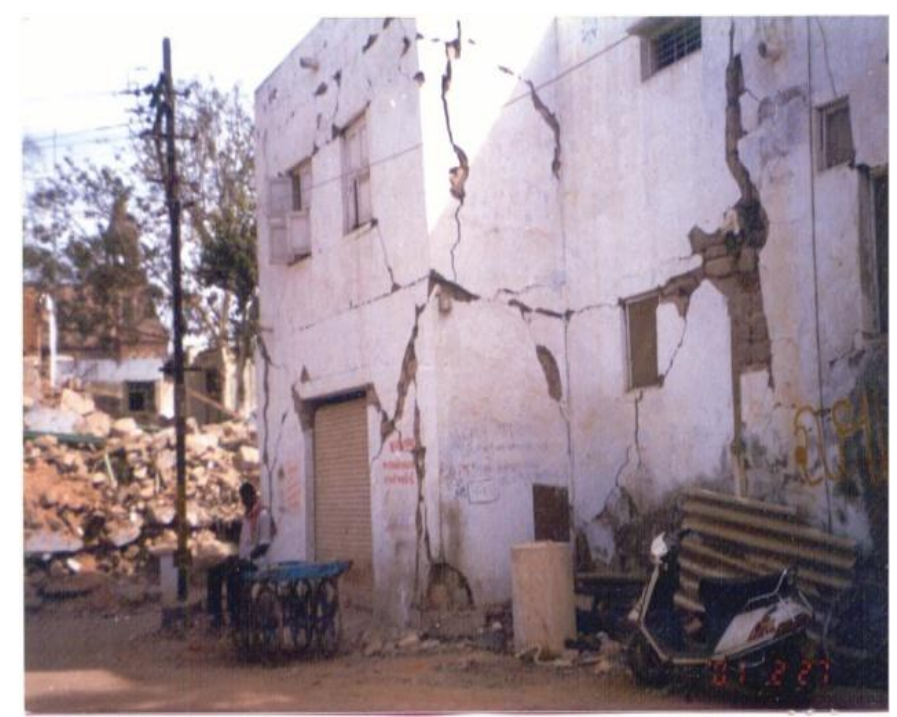

Photo-4: Wide spread cracking in building

In Ahmedabad city, relatively less percentage of buildings suffered damage when compared to Bhuj. However, some of the buildings suffered very severe damage and even collapsed. A few multi-storied buildings with floating columns (photo-5) were also seen to be damaged .Wide spread cracking in walls and structural elements ,buckled and distorted columns (photo-6) , cracked and excessively deflected beams, poorly concreted beam column junctions (photo-7) and critically damaged lift cores and staircases marked the scenes in the damaged building sites . Photos (8) and (9) present the typical failure patterns of structural elements in the buildings of Ahmedabad city .

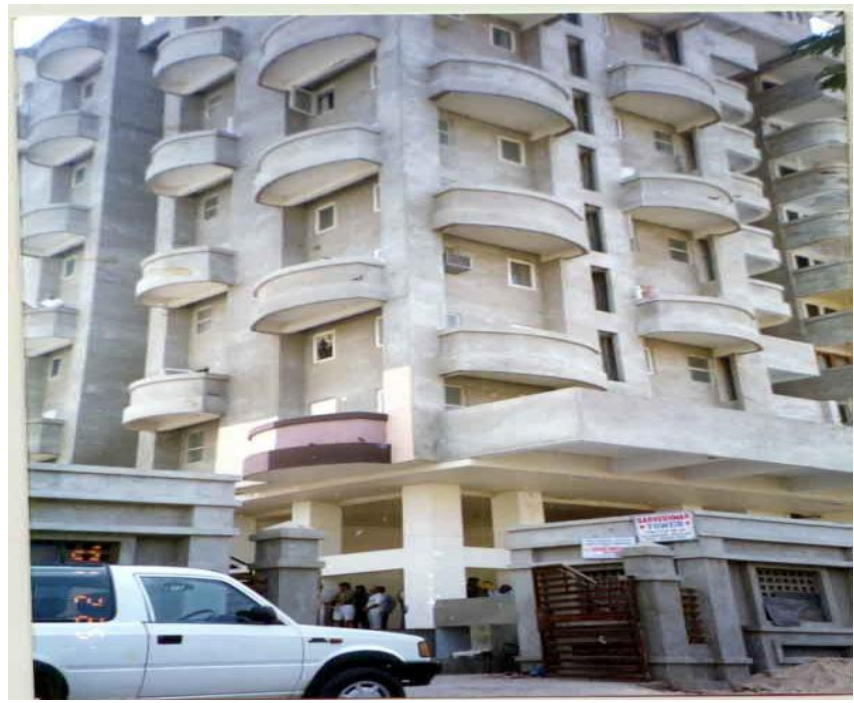

Photo-5: Floating columns

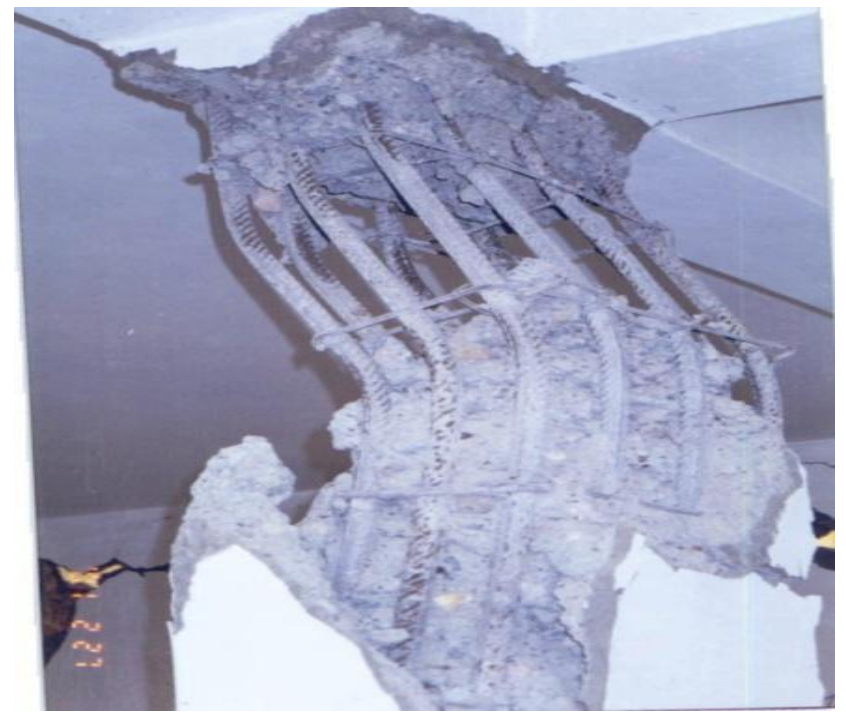

Photo-6: Buckled Columns

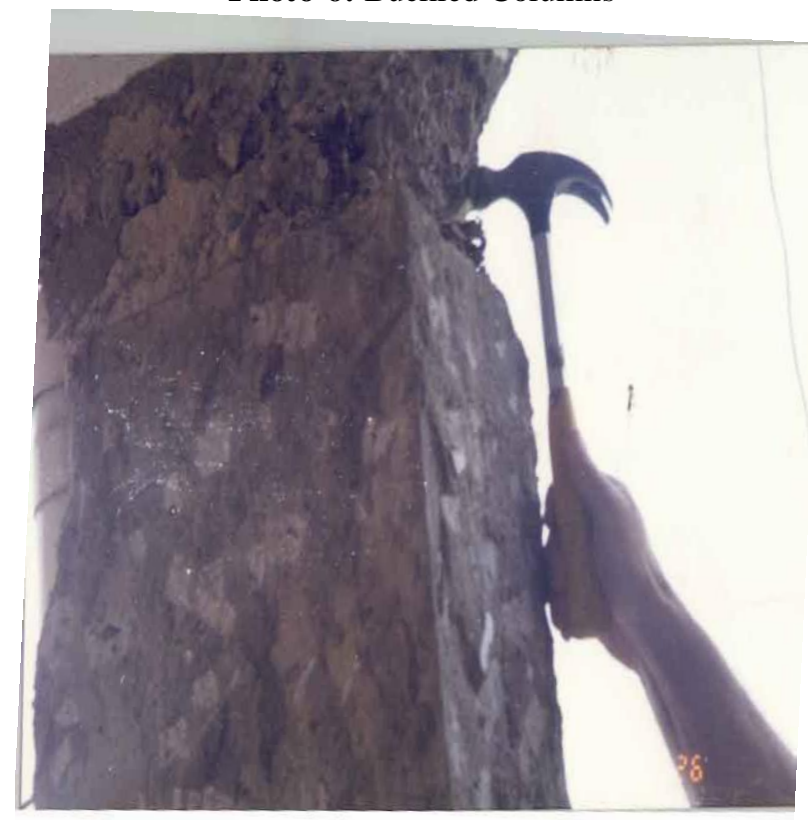

Photo-7: Poor concreting 


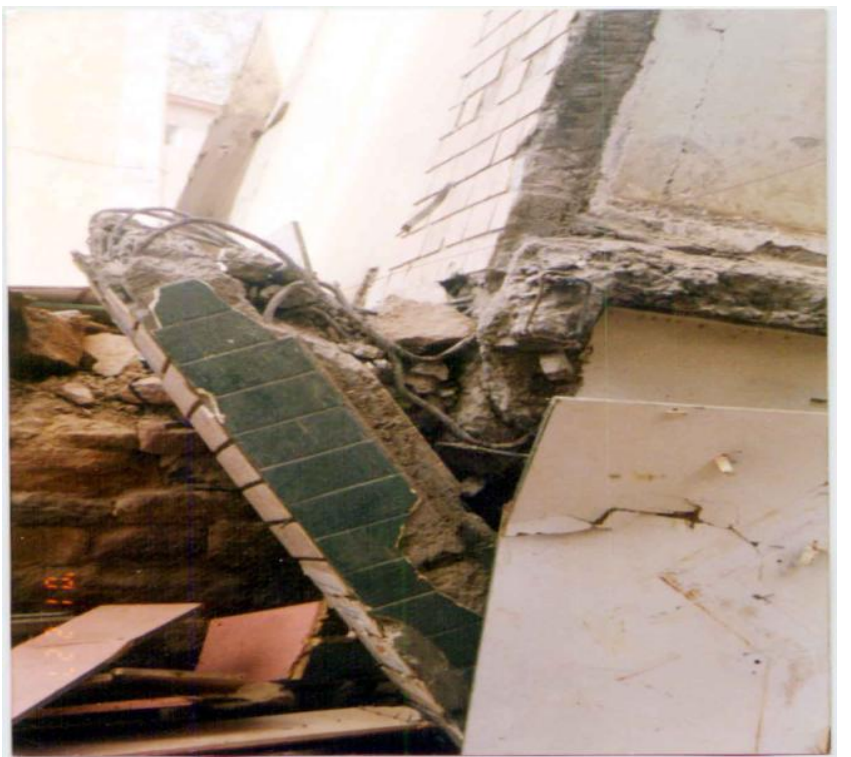

Photo-8: Fractured Columns

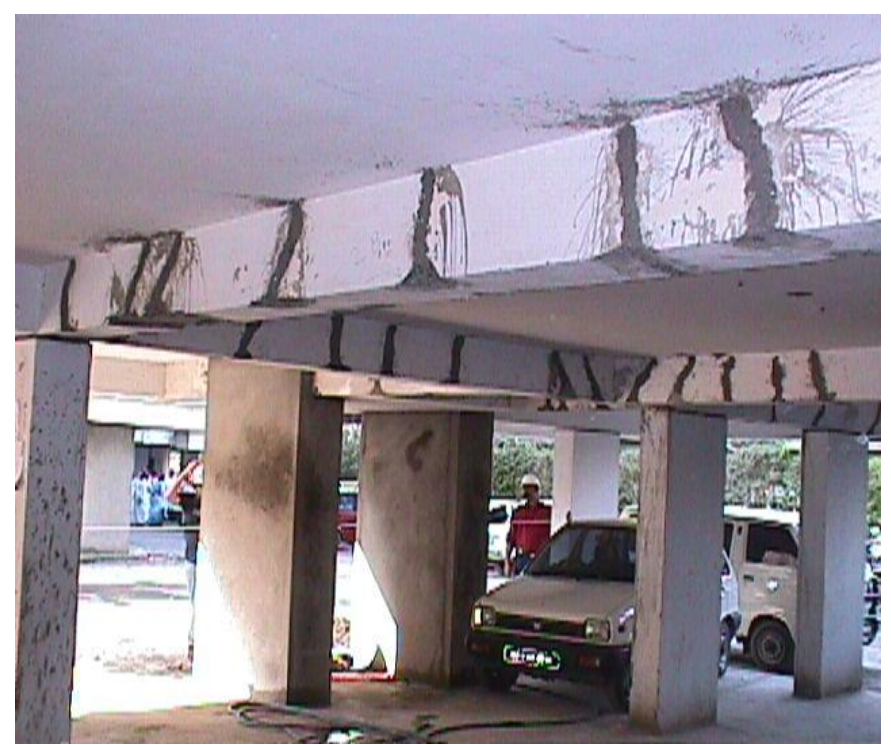

Photo-9: Spiral cracking in beams

\section{FACTORS OBSERVED TO HAVE ENHANCED THE IMPACT OF DISASTER}

In Bhuj town : Even when the 'Griha Seva' team arrived in Bhuj, after about three weeks of the very occurrence of the event also, no major clearing operation or restoration operation could be taken up either by the Government or private organizations. That was because the number of buildings collapsed was large and the debris was so huge that the disposal was a problem . Added to this, the narrow lanes of Bhuj town (photo-10), which were further narrowed down by the very presence of debris on either side and the unprecedented rush of unrelated persons in the form of visitors to the town. There was no control, whatsoever, on this issue due to many reasons. It was really difficult to segregate the crowd in to professionals, visitors and the relatives of the affected who came in search of them. It was in fact the disciplined attitude of the visitors that was required at that juncture, which would make their appropriate help reach the effected area rather than themselves. Rescuing the bodies, clearing the debris and taking up emergency rehabilitation activity was almost impossible at that stage. Disposal of the debris was another serious problem that needed attention. Important structures like hospitals were severely hit and the number of casualties and injured were too high to be attended.The team of 'Griha Seva' under these conditions felt appropriate to stay in Ahmedabad and continue it's operations.

From among the technical observations made which contributed for the enhancement of the impact of disaster , the following were note worthy .

- Improper planning and injudicious approval and construction of buildings, without leaving the required space and even set backs on the road side as well as al round the buildings. The closer proximities of the buildings with one another not only caused debris clearing difficult but also caused pounding (photo-11) and collapse of adjacent buildings in quite a number of cases.

- $\quad$ Non-engineered way of constructing structures with defective materials and faulty execution procedures .Serious violations of design and detailing rules that should have otherwise been followed strictly in such very severe seismic zones (zone-v).

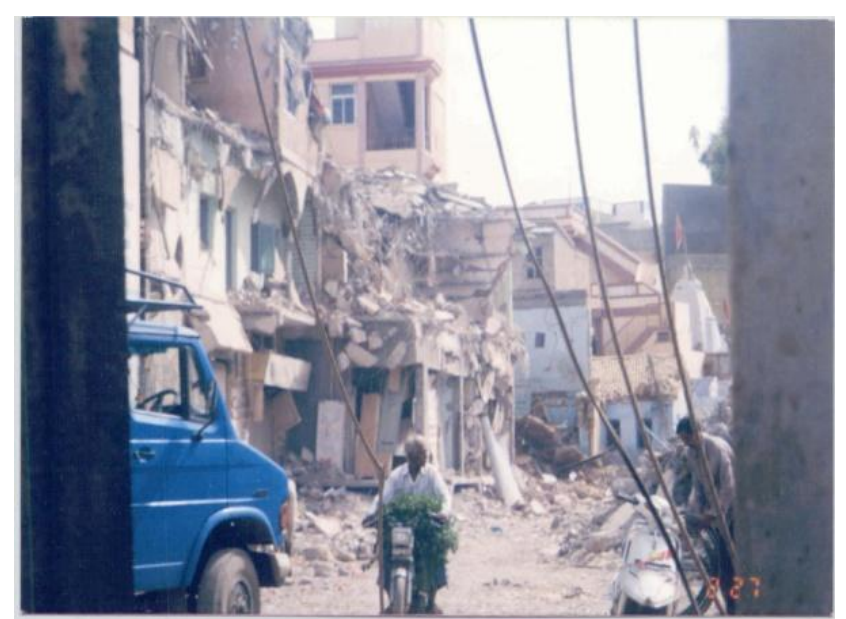

Photo-10: Narrow lanes

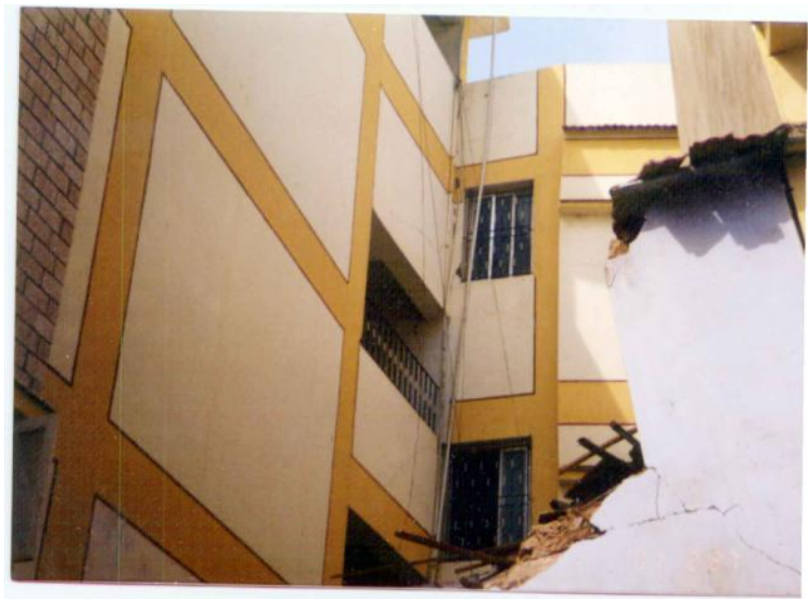

Photo-11: Pounding of buildings 
In Ahmedabad City : This city, the capital of Gujarat a state which was just recovering from drought that occurred in the previous year, was relatively safe though experiencing the problems of accommodating refugees, visitors etc., and increased prices of commodities . Despite these issues, the city became the focal point of all disaster management activities, with several government nominated organizations, NGOs and Voluntary organizations coming forward for the cause. The primary challenge for the administrative authorities was to categorize and prioritize the various quake hit sites in terms of the extent of damage and in order of the urgency required to rehabilitate the structures. Partially damaged structures were raising greater concern as the inhabitants were growing panicky with the after shocks still continuing and the status of structural safety not known. The issues being so technical, there was a great demand for teams of professional engineers to volunteer and act. It was due to this reason that the collector of Ahmedabad appreciated the members of the 'Griha Seva' team, saying that they did a commendable job in the hour of the need .

From among the technical observations made which worsened the effects of disaster, the following were noteworthy .

- Inappropriate retrofitting measures adopted that were lacking any engineering judgment ( refer to photo-12).

- $\quad$ Failure to adhere to the important detailing rules of reinforcement(photo-13), which otherwise are 'must to follow' in such severe seismic zones .

- Injudicious use of floating columns in multi-storied structures .

- Defective materials and faulty workmanship (photo14).

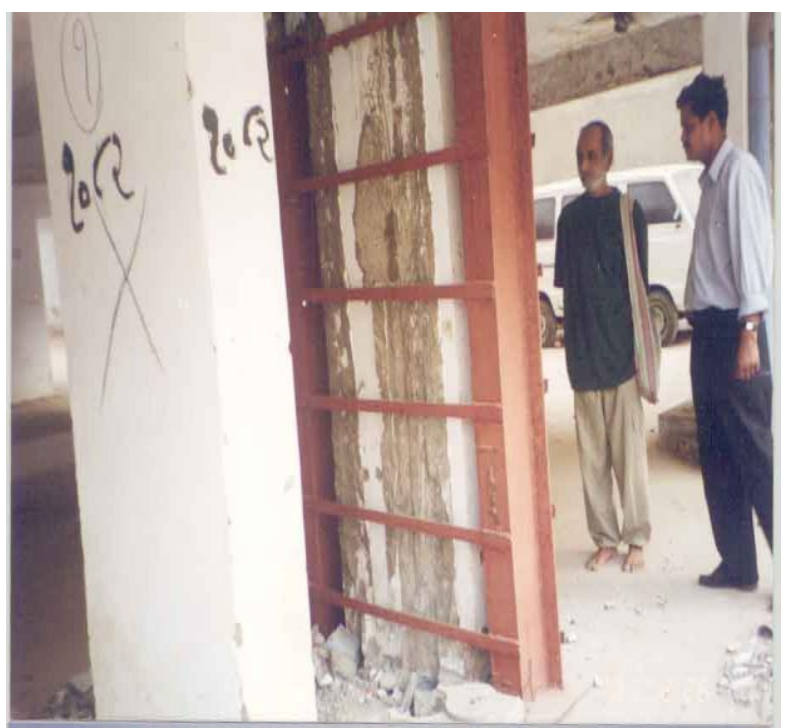

Photo-12: Improper retrofitting

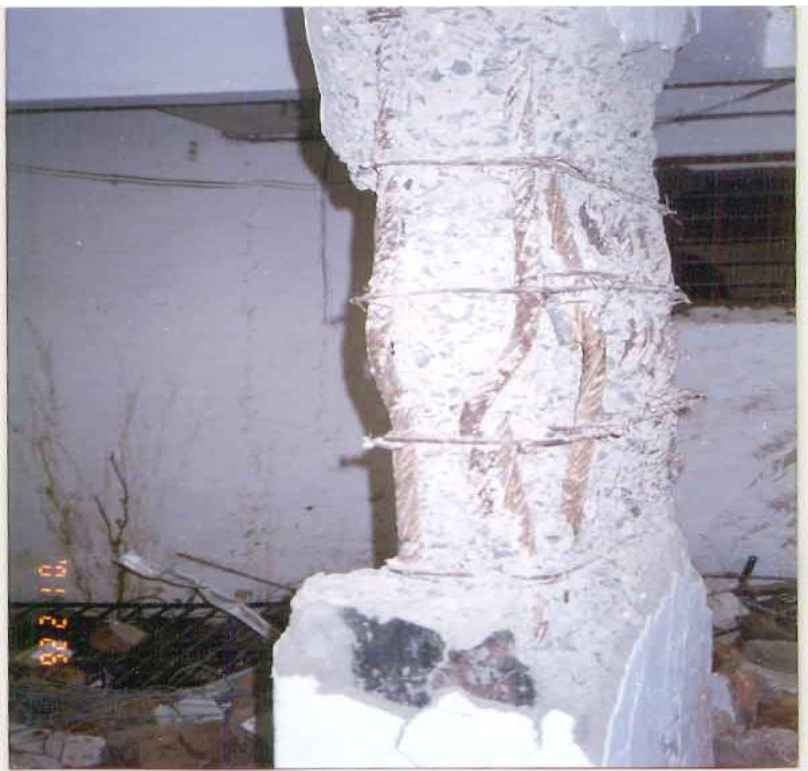

Photo-13: Poor detailing

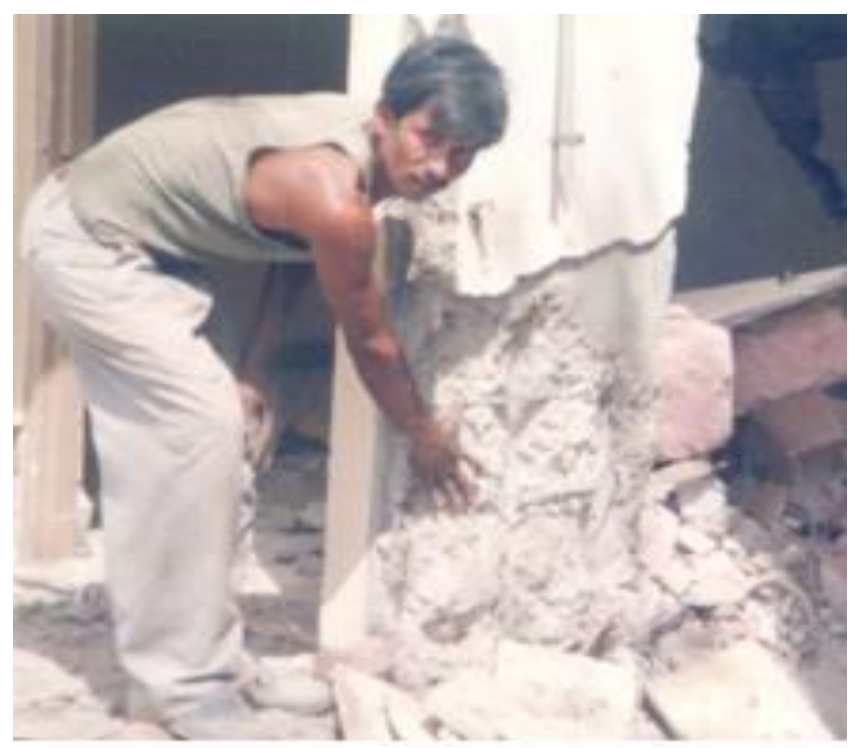

Photo-14: defective wrokmanship

\section{ROLE OF VOLUNTARY TEAMS OF}

\section{PROFESSIONALS}

In the event of any disaster such as the Bhuj earthquake, it is very common for normal public to be emotional, excited and enthusiastic to visit the place and / or donate money ,clothes, food etc. However, such disasters require a professional approach in mitigating and managing them. Civil engineering professionals have a very crucial role to play in this context and must therefore volunteer to serve the structures and the people. A disaster could turn out to be a catastrophe, if unrelated people rush to the effected site and try to act without the knowledge of the subject .Site visits , compilation of data, Analysis, Reanalysis , Designs , Decisions on debris clearance/retrofitting are all technical issues that require professional expertise. Hence, this aspect should be borne in mind and true professionals must come forward to volunteer and serve, during the disasters . 


\section{CONCLUSION}

- Post disaster works must be attempted with lot of strategic planning in the developing countries like India.

- Civil engineering professionals must team up and volunteer to come forward and serve during the disasters such as earthquakes.

- Unnecessary rushing of unrelated persons to the disaster affected places and their injudicious intervention will only enhance the impact of the disaster and may even turn it in to a catastrophe ; hence should be avoided.

\section{ACKNOWLEDGEMNTS}

The authors would like to profusely thank Mr.Mohan G.Ramanathan, for leading the 'Griha Seva' team from the front and Mr.Viral Jassubhai for extending local support at Bhuj and Ahmedabad besides giving hospitality and accommodation . Further, they wholeheartedly thank Mr.Srinivas, the then collector of Ahmedabad, for his encouragement and appreciation given to the 'Griha Seva' team . Author-1 thanks the management of his institution for permitting him to participate in this service oriented activity.

\section{REFERENCES}

[1] Sreenivas Sarma . P, Expert lecture on " Lessons learnt from Gujarat Earthquake of $26^{\text {th }}$ January,2001" , A state level meet conducted on $22^{\text {nd }}$ April , 2001at Kodad, Andhra Pradesh, India. 